\title{
THE REPRESENTATION OF CULTURAL HERITAGE FROM TRADITIONAL DRAWING TO 3D SURVEY: THE CASE STUDY OF CASAMARY'S ABBEY
}

\author{
M. Canciani ${ }^{\mathrm{a}}$, M. Saccone ${ }^{\mathrm{a}},{ }^{*}$ \\ ${ }^{\mathrm{a}}$ Dipartimento di Architettura, Università degli Studi Roma Tre - (marco.canciani, mauro.saccone)@uniroma3.it
}

\section{WG V/2 - Cultural Heritage Data Acquisition and Processing}

KEY WORDS: Integrate survey, Documentation of Cultural Heritage, Traditional and modern representation

\section{ABSTRACT:}

In 3D survey the aspects most discussed in the scientific community are those related to the acquisition of data from integrated survey (laser scanner, photogrammetric, topographic and traditional direct), rather than those relating to the interpretation of the data. Yet in the methods of traditional representation, the data interpretation, such as that of the philological reconstruction, constitutes the most important aspect. It is therefore essential in modern systems of survey and representation, filter the information acquired. In the system, based on the integrated survey that we have adopted, the 3D object, characterized by a cloud of georeferenced points, defined by their color values, defines the core of the elaboration. It allows to carry out targeted analysis, using section planes as a tool of selection and filtering data, comparable with those of traditional drawings.

In the case study of the Abbey of Casamari (Veroli), one of the most important Cistercian settlement in Italy, the survey made for an Agreement with the Ministry of Cultural Heritage and Activities and Tourism (MiBACT) and University of RomaTre, within the project "Accessment of the sismic safety of the state museum", the reference 3D model, consisting of the superposition and geo-referenced data from various surveys, is the tool with which to develop representative models comparable to traditional ones. It provides the necessary spatial enviroment for drawing up plans and sections with a definition such as to develop thematic analysis related to phases of construction, state of deterioration and structural features.

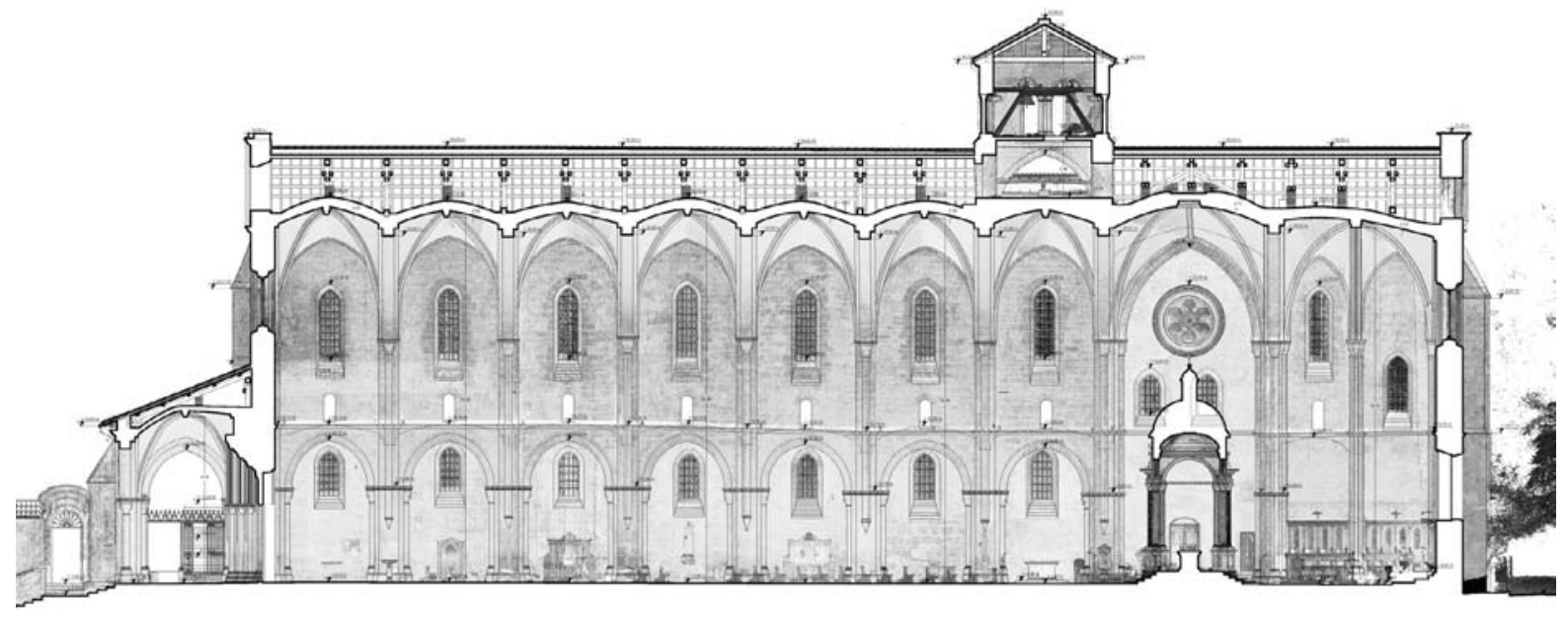

Figure 1a. The Abbey of Casamari (Veroli): Longitudinal section, Survey elaboration (2014)

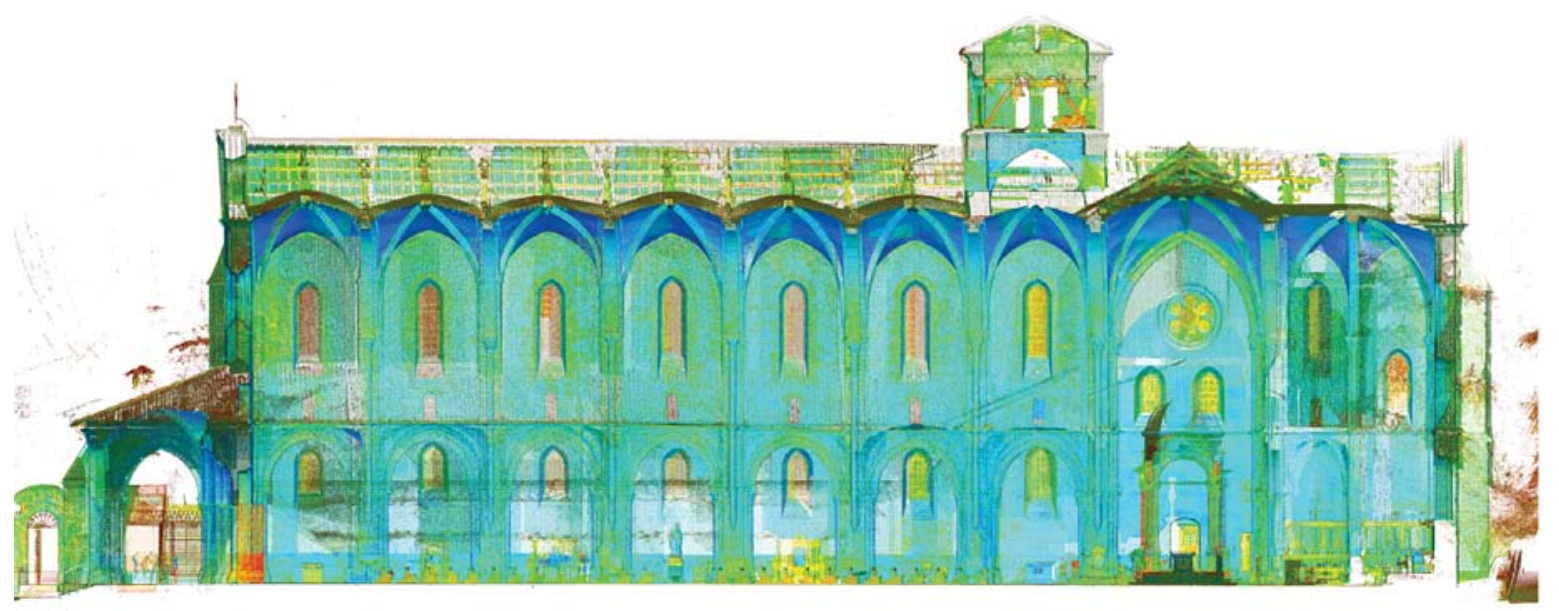

Figure 1b. The Abbey of Casamari (Veroli): Longitudinal section, the reflectance image (2014)

* Corresponding Author 


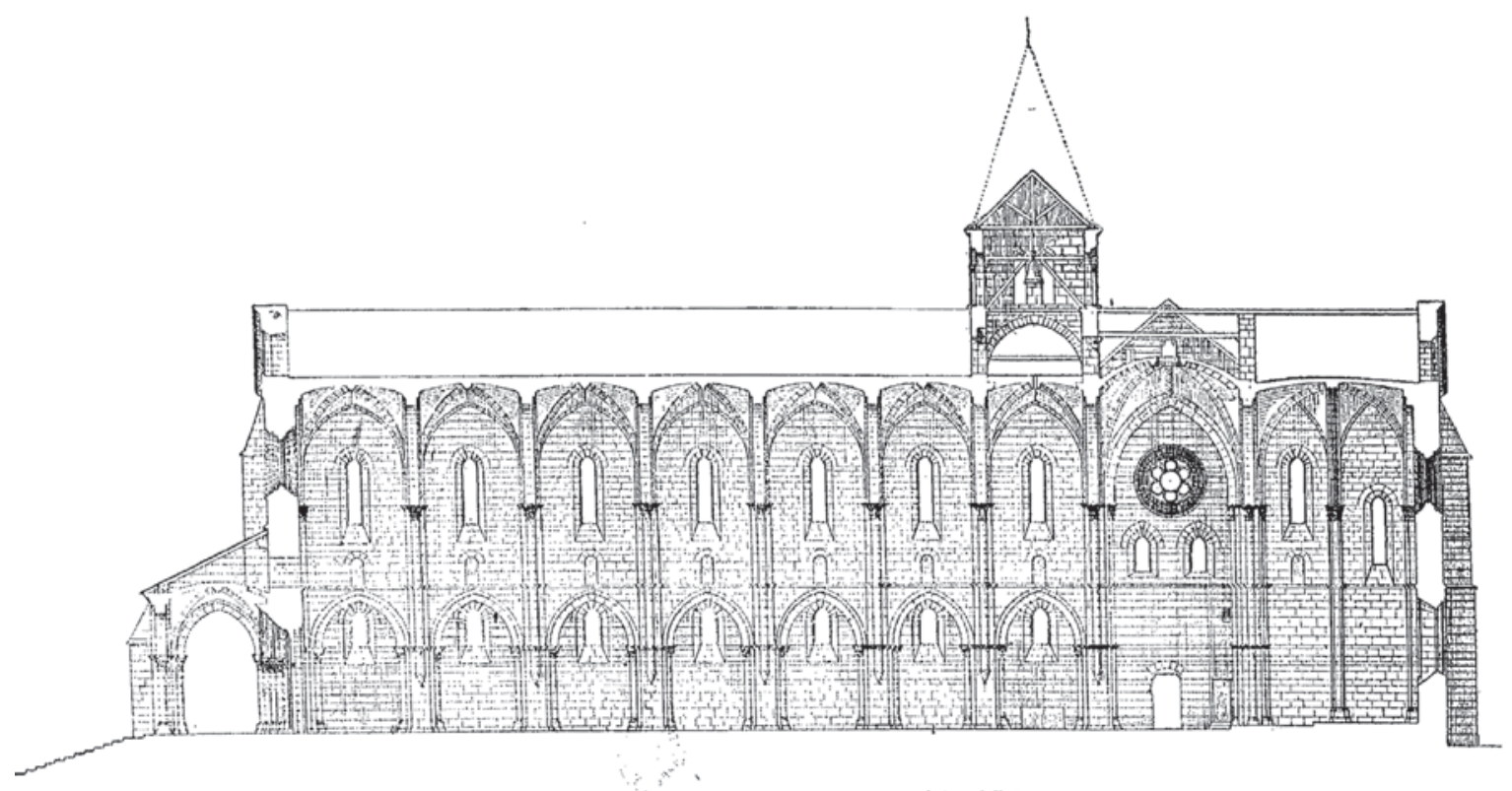

Figure 1c. The Abbey of Casamari (Veroli): Longitudinal section, Elaboration by C. Enlart (1894)

\section{INTRODUCTION}

In an architectural survey aimed at the preservation or restoration of a structure, such as the Abbey of Casamari "the simple geometrical knowledge - morphological aspects of a building structure, while important, it is not sufficent to ensure the correctness of further interventions on it" (Docci - Maestri, 2009, p. 7).

Whilst drawing survey is the basic support for the analysis of a building, it anticipates, to a certain extent, the specific elements that are subject to such analysis, starting from those of Constructive and Stratigraphic Survey (Harris, 1975; Francovich - Parenti, 1978) and Critical Survey (Francovich, 1985; Brogiolo, 1991; Carbonara, 1985; Doglioni - Gabbiani, 1985; Parenti, 1985). For that purpose, the drawings should be able to describe all the characteristic features of the building, in addition to numeric and dimensional ones: the masonry layers, the characteristics and the material properties, the working and installation, the construction details, architectural anomalies and the building phases etc. This process, in order to be it as much empathy with the surveyed bject (Bertocci - Bini, 2012, p.317), it is necessary that the scholar of an architectural work, should devote a special attention to matching survey - object, in his dual role of surveyor and renderer, guaranteed only by a direct contact with the architectural work and survey - representation, according to well-defined specifications, which survey drawings should always guided by. In view of these considerations, survey drawings (Figure 1a) must relate, both to survey numeric data, represented, for example, by the reflectance image (Figures 1b), as to the historical documentation (Figures 1c), such as the drawing by C. Enlart (1894), which constitutes not only a useful point of comparison for futher analysis, but also a precise exemplification where the survey graphics processing should refer.

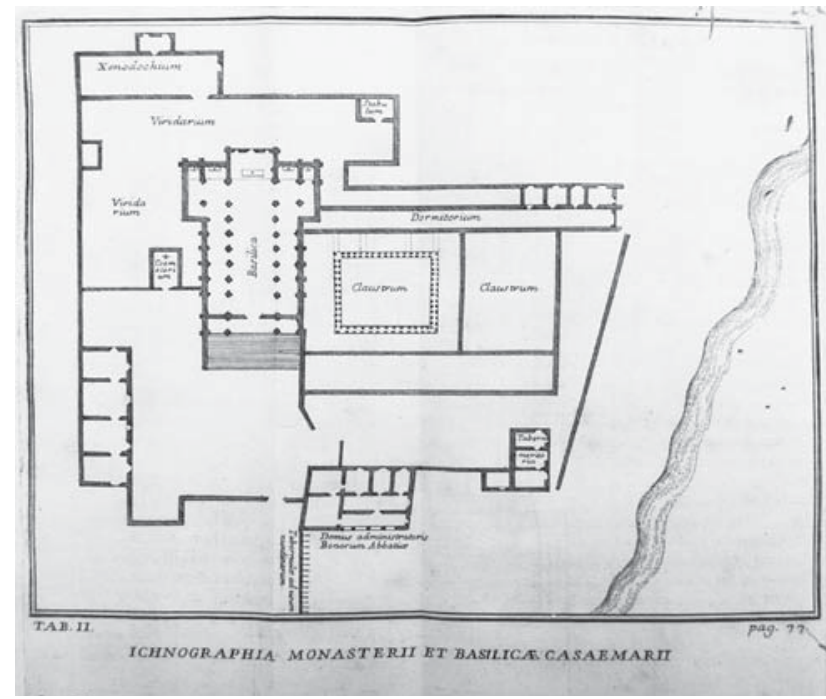

Figure 2a. Plan of F. Rondinini (1207)

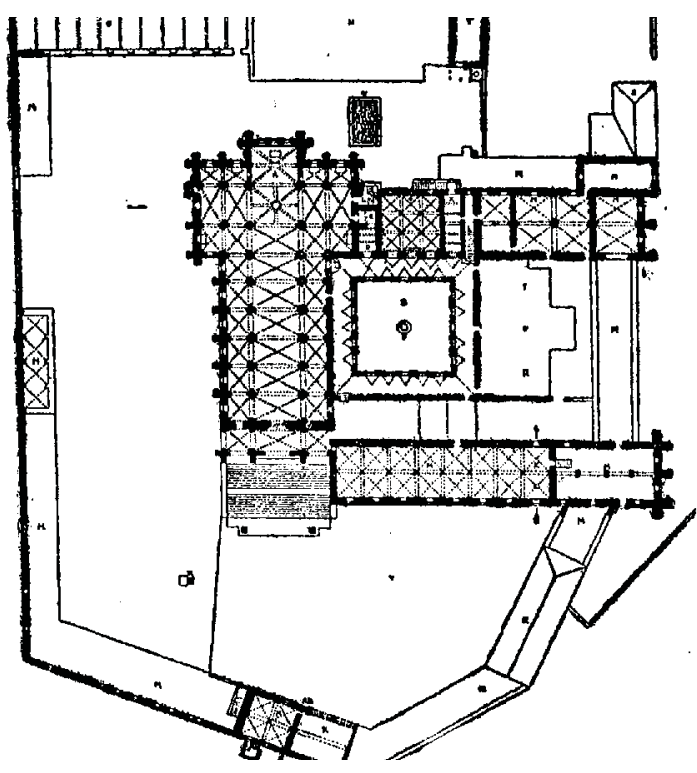

Figure 2b. Plan of C. Enlart (1894) 


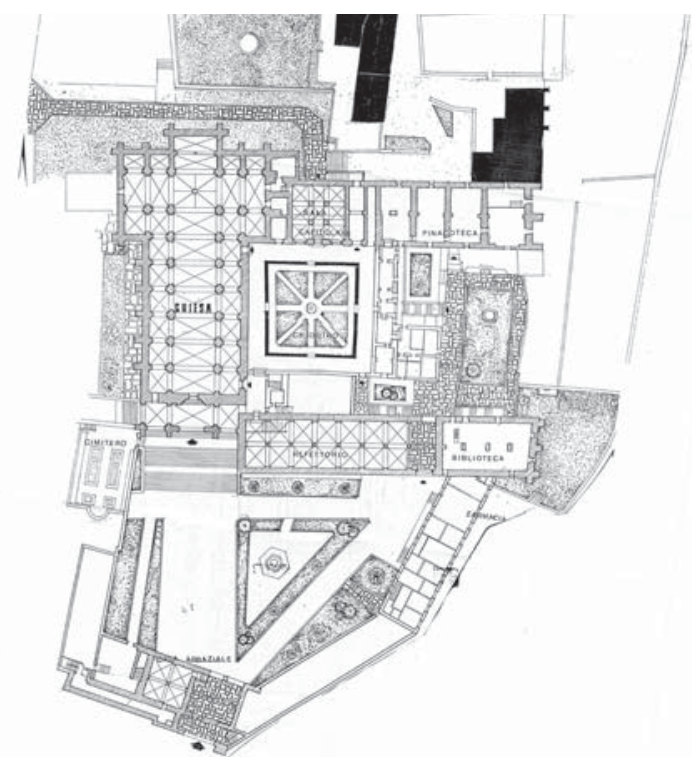

Figure 2c. Plan by Picuti (2008)

\section{THE CASAMARI'S ABBEY AT VEROLI}

The object of study, which is the complex of the Casamari's Abbey, is a test case where to apply a survey methodology that takes into account both the morphological aspects as those constructive and transformative ones. The complex, located near the town of Veroli (Lazio) and composed by various buildings (including the church, the cloister, the museum, the refectory, the dormitory) spread over a large area (about $26,600 \mathrm{~m}^{2}$ ), it is one of most important examples of Cistercian architecture in Italy.
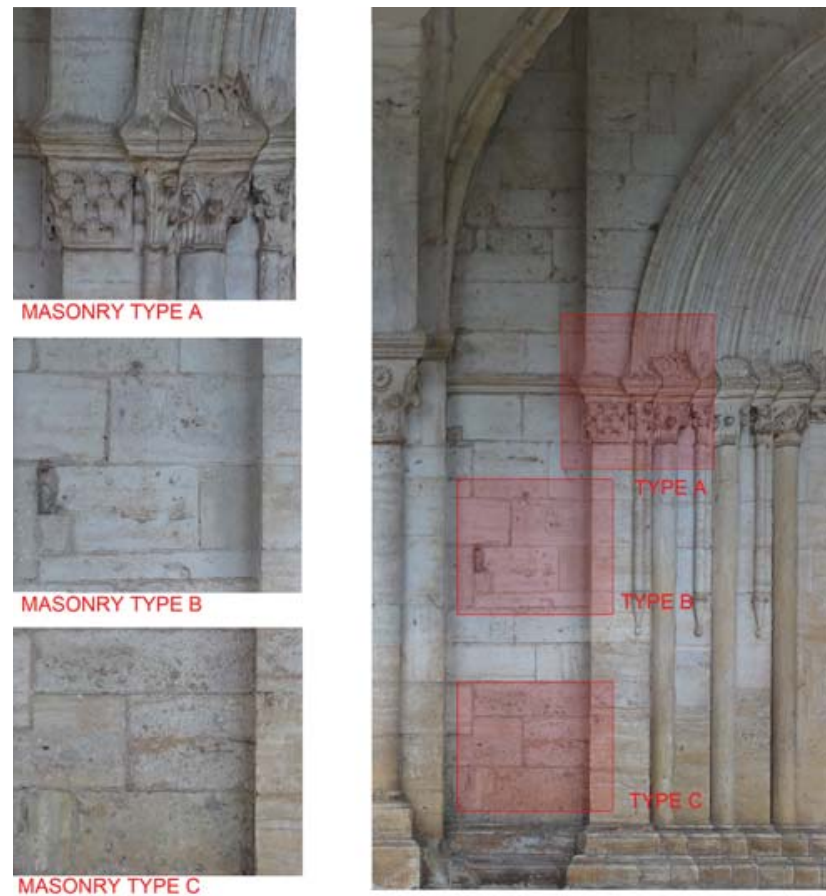

Figure 3a. Masonry Type of the Church

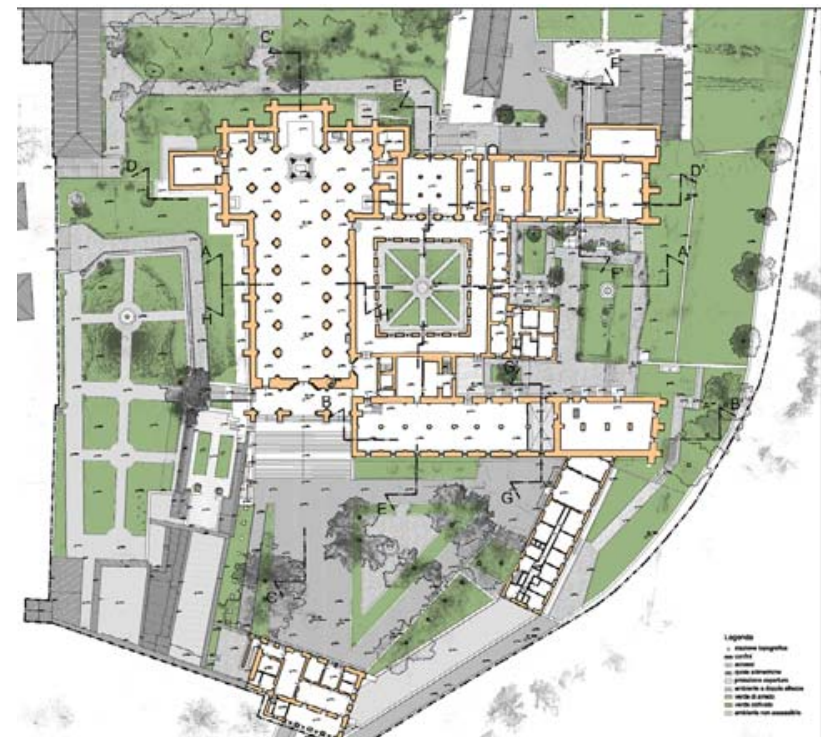

Figure 2d. Survey Plan (2014)

\subsection{Study about historical documentation}

Based on the literature on the Abbey, especially (Rondinini, 1707; Enlart, 1894; Scaccia Scarafoni, 1962; Farina and Fornari, 1978; Picuti, 2008), the iconographic documentation, including the plan of the Gregorian Catasto, 1824, and previous surveys, made during the recent restorations by the Superintendency, it can be assumed that the Abbey, built in the first phase by Benedictine monks around the 1036, on the ruins of an ancient Roman settlement, was restored by the Cistercian monks between 1151 and 1217. After a devastating earthquake, in 1350, the complex

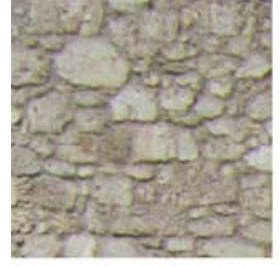

MASONRY TYPE D

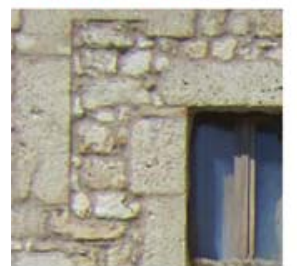

MASONRY TYPE E

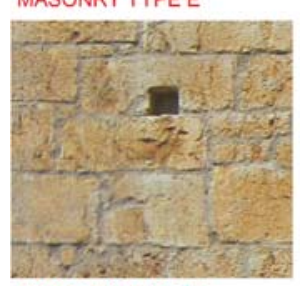

MASONRY TYPE F

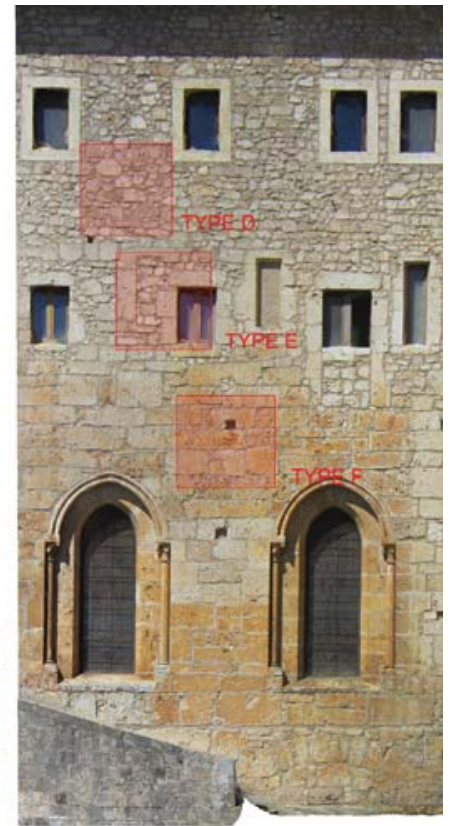

DETAIL A
Figure 3b. Masonry Type of the East Façade of the Dormitory 


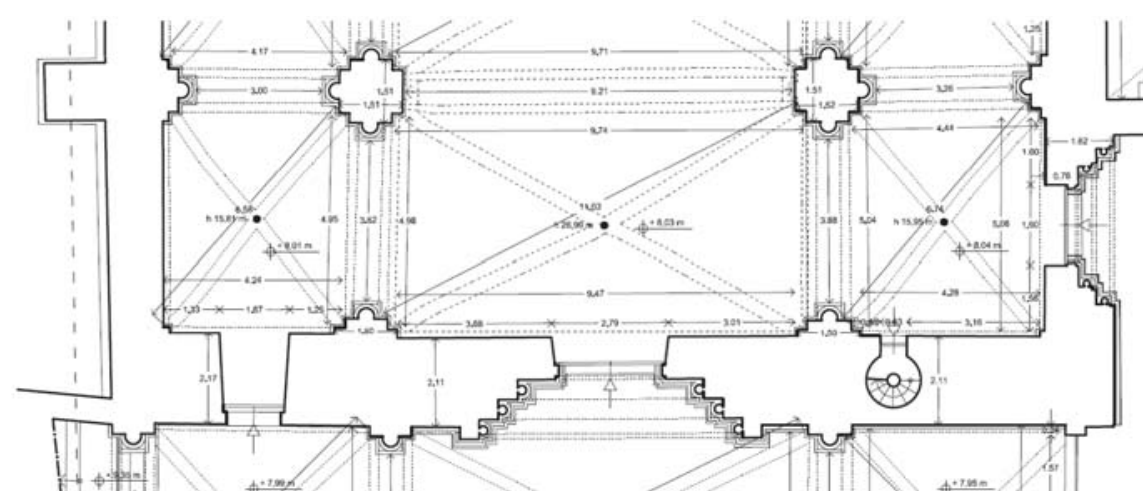

Figure 4a. Detail of the Plan of the church

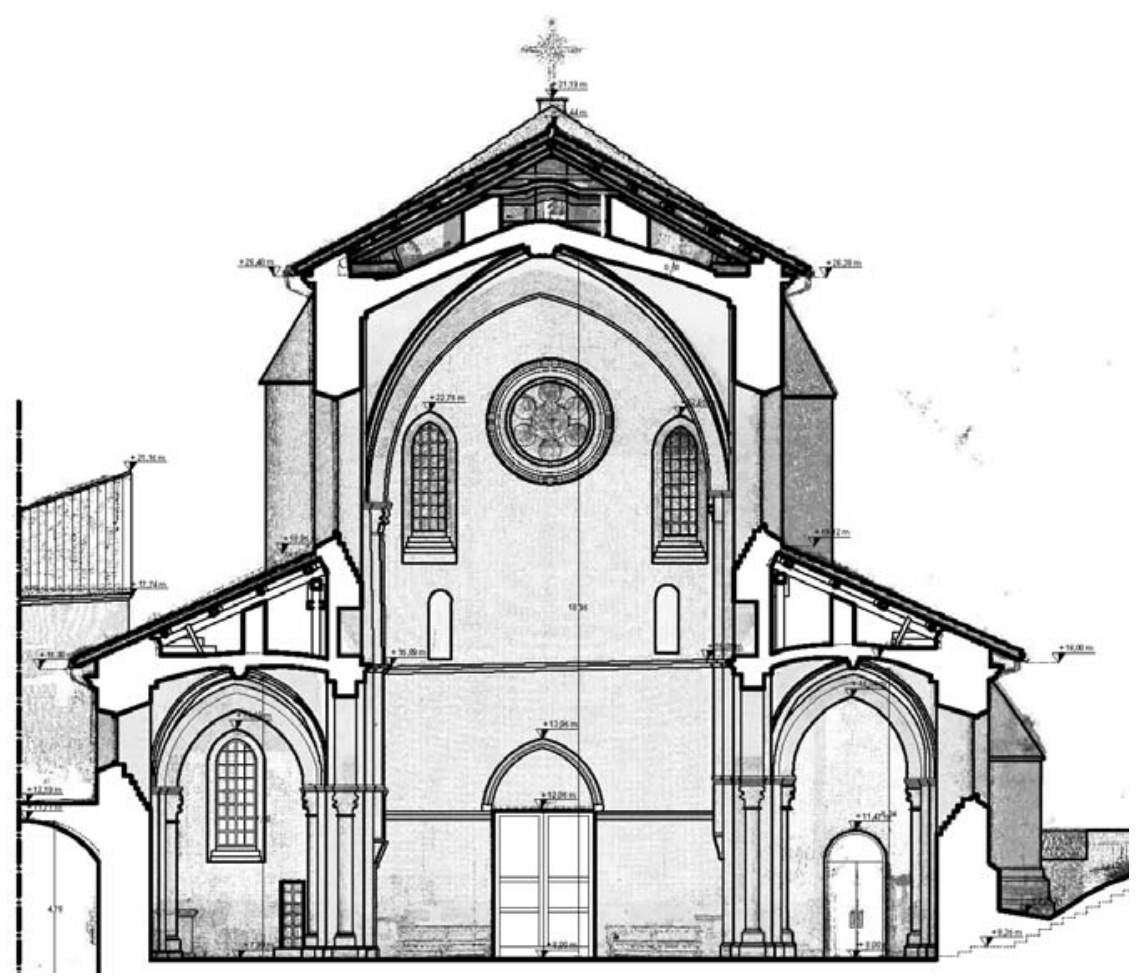

Figure 4b. Cross section, looking at the church counterfaçade

fell into a state of progressive decay and abandonment. Some limited restoration works have been made in the mid-sixteenth century and other most important, in the early eighteenth century, rose again the fate of the Abbey. Throughout the nineteenth and twentieth centuries several restoration projects have been realized, including some hearty in the early 80 s and 90 s.

\subsection{Study and survey on the current status}

In 2014 an agreement with the Ministry of Cultural Heritage and Activities and Tourism (MiBACT) and University of Roma Tre, within the project "Accessment of the seismic safety of the state museum", has allowed to develop a detailed study about the Casamari's Abbey, involving scholars from different disciplines, such as Building Science, Representation and Restoration (1). In this context a survey campaign of the entire complex was made (2), adopting the methodologies applied in different experiences

1 The work group is composed by: G. De Felice (Scientific Responsible and Coordinator of Investigation and structural Analysis), M. Canciani (Coordinator of geometrical and architectural Survey), M. Zampilli
(Canciani - Spadafora, 2014). The work was developed in four different phases:

a. An initial phase of cartographic framework _ according to a geographic coordinate system and the acquisition of historical documentation and previously carried out surveys.

b. A second phase of collecting data on site realized through various integrated procedures: topographic framing survey $(20$ stations and 8200 points); 3D laser scanner survey (72 stations and 1,896,000,000 points); photogrammetric survey (1500 photos and 56 models); Direct survey (various measurements and processing of general and detailed hand drawings).

c. A third phase of data into three-dimensional models processing in which the acquired data were processed in $3 \mathrm{D}$ modeling software (60 3D models, some specific models for structural modeling and analysis).

d. A fourth phase of the final graphics processing divided into: 4 general drawings in scale 1: 200 (floor plans and profiles); 17 partial plants in scale 1: 100 (church, museum refectory, cloister, abbot residence guest house, office); 8 sections on a scale 1: 100

(Coordinator of historical-critical Survey and constructive Survey) 

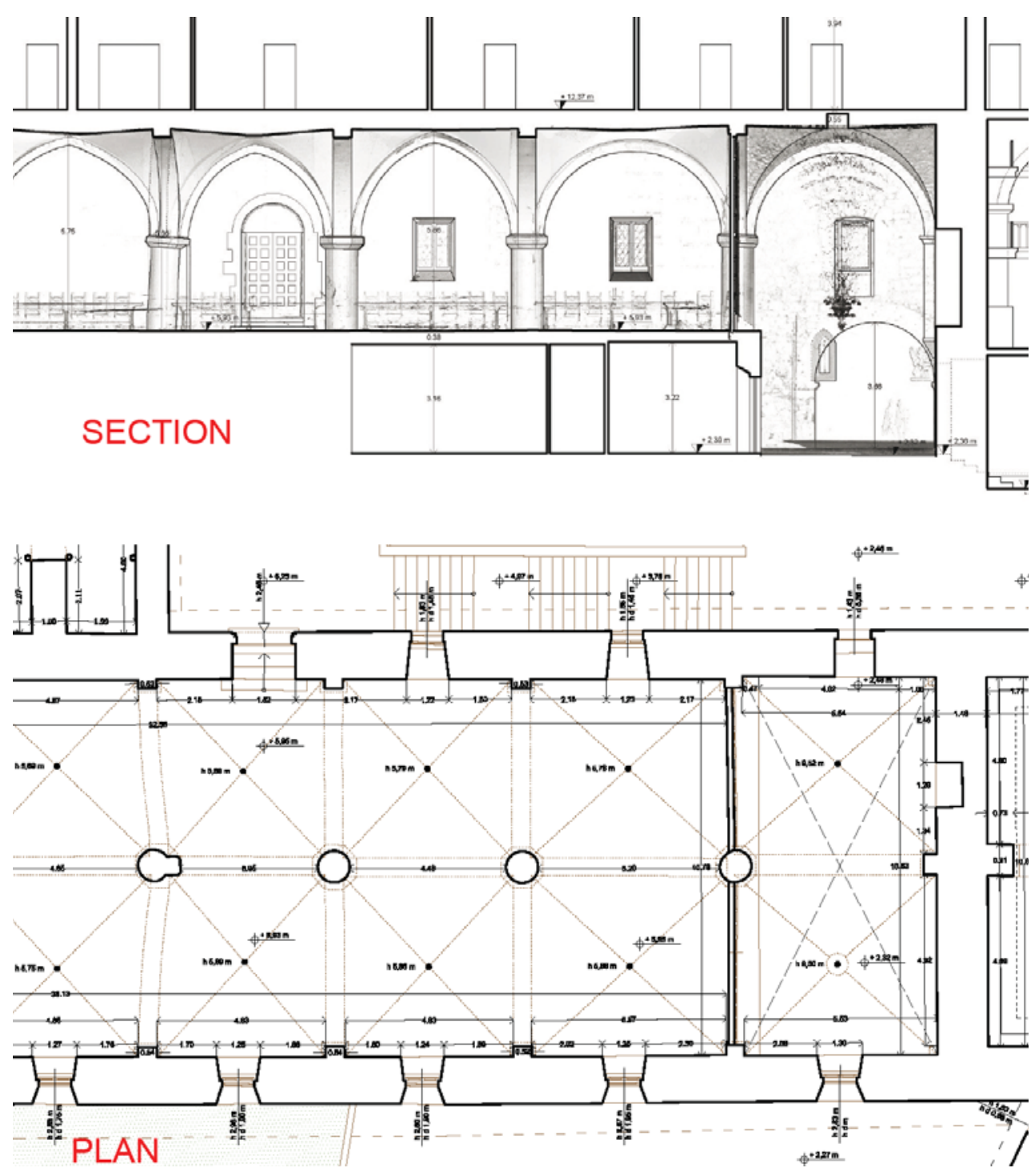

Figure 5a, b. Refectory: Longitudinal Section and Plan

(from A-A' section to H-H' section); 4 elevations in scale 1: 100 (North South East, West) (3).

\subsection{Analysis and comparison}

On the basis of the survey drawings, comparing them with historical documents it was possible to carry out some analysis regarding specific issues: a) analysis of the planimetric configuration b) analysis of masonry types and details c) analysis of structural anomalies and differences.

\section{a) Analysis of the planimetric configuration}

A first layout, defined between 1151 and 1217 and documented by the map shown in (Rondinini F. 1707) (Figure 2a), develops according to a typical type of Cistercian settlements (also taken in the Abbey of Fossanova, coeval with that of Casamari and made by the Burgundian workers.); a square central Claustrum around which other buildings are located: _the Basilica to the north, the Dormitorium to the east a second Claustrum, south a building in West; the Abbot's residence disposed on the perimeter wall above the entrance of the complex. On the next map on the Gregorian Cadastre of 1824 and shown in (Enlart C. 1894) (Figure 2b) it

2 The work group for geometrical and architectural Survey is composed by: M. Canciani (Coordinator), S. Tagliati, A. Ballanti, B. Mammì, M. Michelini, G. Romito, A. Scortecci, S. Strambone is essentially maintaining the previous planimetric configuration with the addition of a building located on the southern front which completes the second cloister built around and some perimeter warehouses. The projection of the intrados of the roof in the map showing the specific structure of the most important spaces including the church, the chapter house, refectory, covered by cross vaults and cloister, covered by a vault with lunettes.

By comparison with the plan by Picuti (2008) (Figure 2c) and survey plan of 2014 (Figure 2d) it shows that the current configuration is basically the same except the building mentioned above now no longer present (on the facade of the museum it is possible to see the traces of the two covering layers of the disappeared building, which stood against the wall) and the addition of new volumes (new sacristy, kitchen etc.). The drawing of site plan scale 1: 200 uses a symbology and a descriptive level that is related to that one of the Enlart drawing.

\section{b) Analysis of the constructive aspects and details}

The architectural survey drawings, whose definition and graphic resolution allows a precise and detailed reading of the wall texture, provided the basis for the analysis of the constructive aspects, the masonry stratigraphy and typologies.

Taking the main facade of the church as an example it denotes in the lower range the use of a rather regular and homogeneous masonry of square blocks of various sizes (Figure 3a, masonry Type C) on which is superimposed at the height of the lintel of 

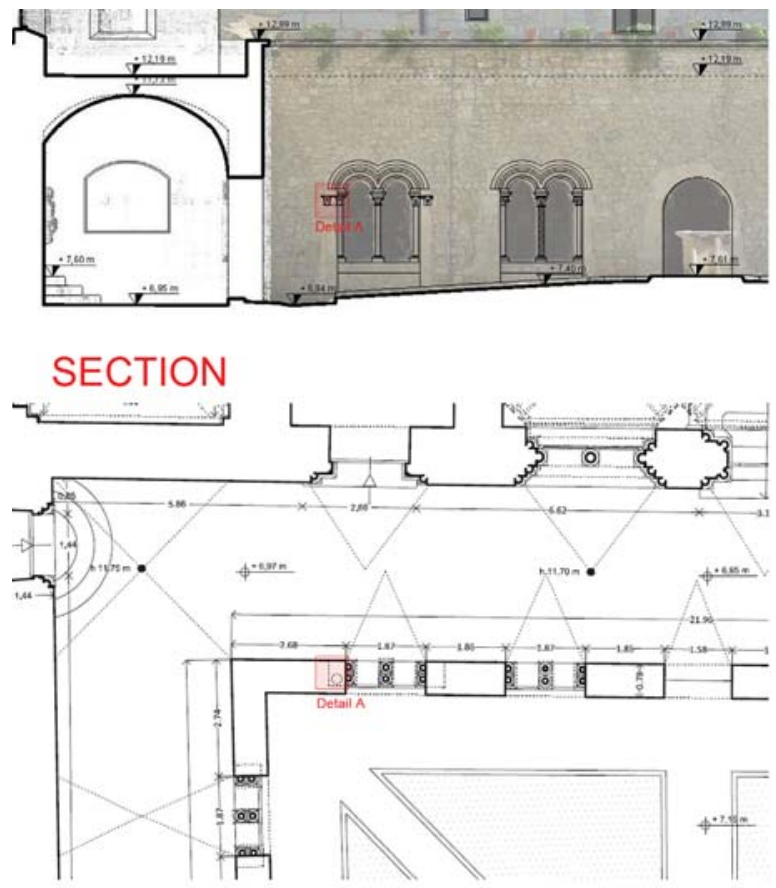

PLAN

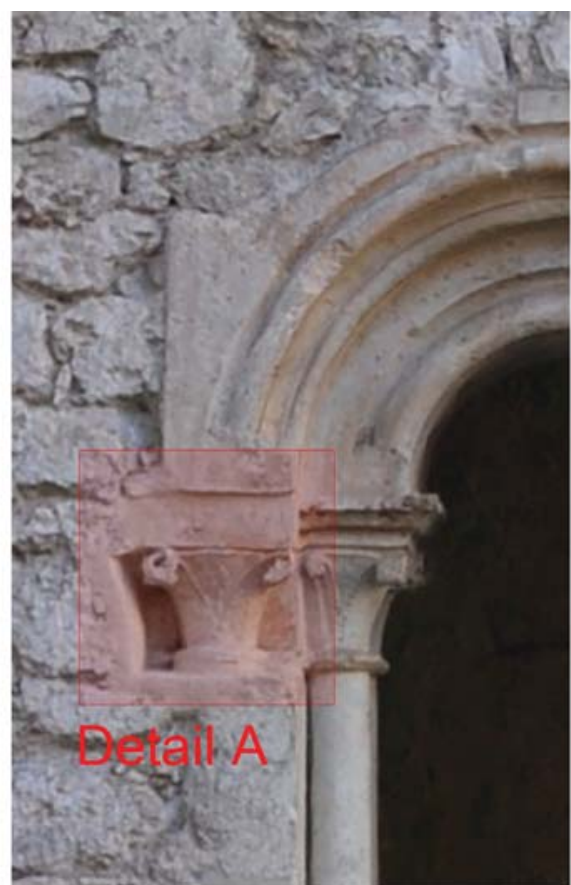

Front view by Photogrammetric

model

Figure 6. Detail of the Cloister

the side doors a masonry (Figure 3a, Type B), consisting of large squared elements of various sizes and different color, probably coming from the counting of pre-existing Roman structures in the area and that testify two subsequent building phases chronologically contiguous.

Even the entrance portal is due to a later phase than that of the wall, being the portal framing set against the vault of the narthex (Figure 3a, masonry Type A).

Looking at the Eastern front of complex the variations of wall texture and discontinuities, it is possible to hypothesize a stratigraphy of the specific segment: a first phase involving the construction of the church and the first two levels of building place to the left and the new sacristy to the right (Figure 3b, Type F). In specific detail the variation of the wall texture also allows to read the transformations that occurred at the open in breach windows, then made in a later phase and those buffered belonging to a contemporary phase (Figure 3b, Type E).

\section{c) Analysis of the anomalies and constructive differences}

An accurate analysis of the current state, as elaborated by the survey graphics compared with historical documents it allows to highlight certain anomalies and deviations from the ideal geometric conformation, useful for understanding the changes that occurred and previous or current alterations.

In particular, concerning the church, in the drawing of the plant are obvious that the projections of the ribs of the voults do not have a linear path but curvilinear (Figure 4a); the projection of the vaults is not placed vertically respect the base of the south wall pillars and this misalignment is also evident in cross section (Figure 4b). In longitudinal and cross section it is still denotes a marked inclination of the intermediate moulding that denouncing a difference in altitude to witness a change in the structure than the optimum configuration, possibly due to a defect in the original construction.

Regarding the bell tower the comparison between the current section of the four-pitched roof covering and the view of Rondinini highlight an original conformation of a more inclined roof. In the section shown by Enlart (1894) the roof is drawn as it is in its present state, but the drawing in broken lines shows a steeper section to testify that the roof, destroyed in a fire around 1890, was rebuilt at that period (Figures 1a and 1c).

Regarding the refectory is evident in the fourth column from the left, a support place as a further backing of vault in correspondence of which in plan is pronounced denotes a shift of the ribs. In the Enlart plan, the refectory has 8 spans and is directly connected with the library (Figure 5a), while in the plan derived from the current survey, set in 7 spans and the 8th corresponds to a space with double height with the masonry of the vault to view and corresponding to the entrance passage to the monastery (built so at a later date to 1894) (Figure 5b).

About the cloister, comparing the plan of Rondinini with that one of Enlart, it can observe the transformation occurs in a period between 1707 and 1894 in which, for a continuous series of attached bifore, it follows a series of bifore separated by little walls just as it is in its present state. The detailed survey made it possible to specify better the study, noting that the first bifora on the left of the western side of the cloister has three capitals: two on the lower inside arch and one on the upper outside arch (Figure 6). This would imply a more complex original configuration than at present.

\section{CONCLUSION}

This paper shows only partially the potential that a survey method specializing in the architectural, morphological or constructive studies, can make to the knowledge and understanding of a building complex as well articulated as the Abbey of Casamari. The huge amount of data organized according to a geospatial reference system allows to select some portions of them on the basis of the section planes used in historical designs in order to make a congruent superposition so as to reveal anomalies and differences (Figure $7 \mathrm{a}, \mathrm{b}$ ). In the survey drawing of the cross section, it is possible to see, both in the central nave and in the lateral ones, the supporting structures of the roof trusses, built after 1894 (not visible in the Enlart drawing), and placed on the kidneys of the voults. 


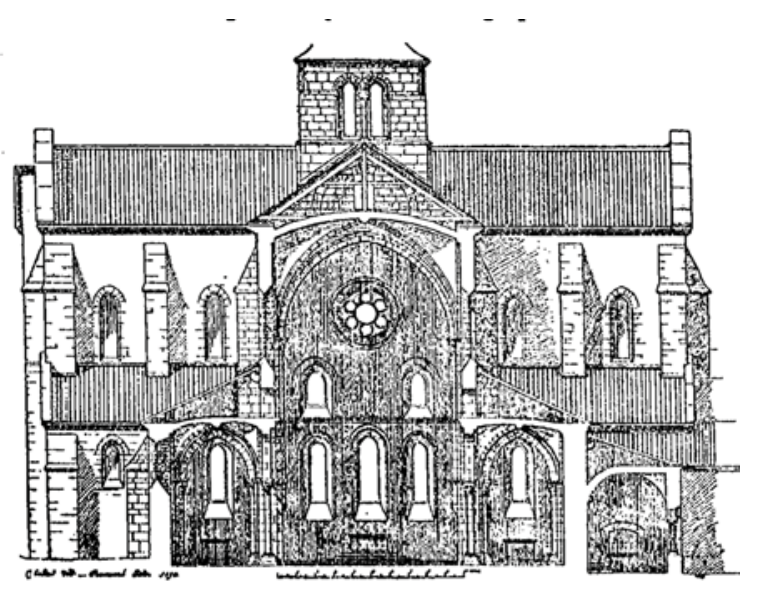

a)

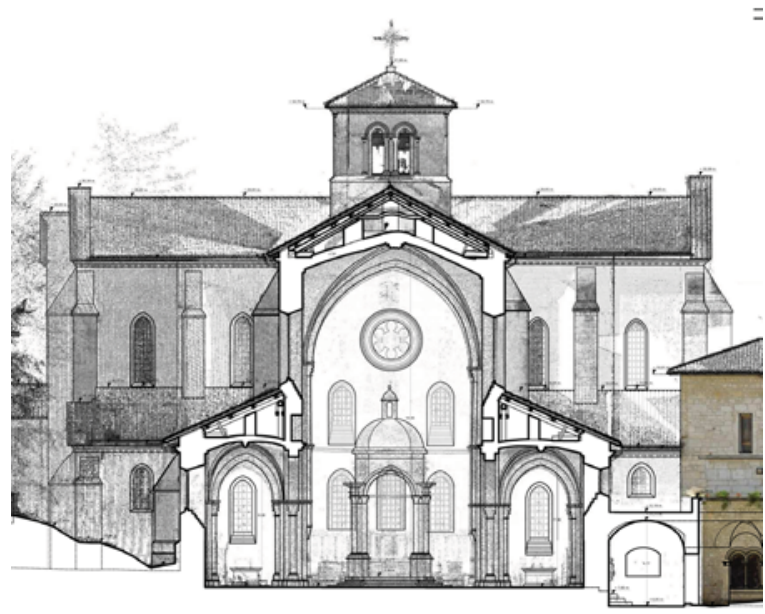

b)

Figure 7. a) Cross section by Enlart (1894);

b) Cross section by Survey (2014)

\section{REFERENCES}

Aliberti, L., Canciani, M., Alonso Rodriguéz, M. A., 2015. New contributions on the dome of the Pantheon in Rome: comparison between the ideal model and the survey model. In: International Archives of the Photogrammetry, Remote Sensing and Spatial Information Sciences, vol. xl-5/w4, p. 291-297

Bertocci S. and Bini M., Manuale di rilievo architettonico e urbano, Città studi edizioni, Novara 2012.

Canciani M. and Spadafora, G., 2014, Differenze metodologiche nel rilevamento $3 \mathrm{D}$, in archeologia e in architettura. In: ITALIAN SURVEY \& INTERNATIONAL EXPERIENCE, Gangemi, Roma, p. $777-783$

Canciani, M., Cennicola, V., Messi, M., Saccone, M., Zampilli, M., 2013. A 3d Gis Method applied to Cataloging and Restoring: the case of Aurelian Walls at Rome. In: XXIV International CIPA Symposium. INTERNATIONAL ARCHIVES OF THE PHOTOGRAMMETRY, REMOTE SENSING AND SPATIAL INFORMATION SCIENCES, Strasbourg, France.

Canciani, M. and Saccone, M., 2011. The use of 3d models in integrated survey: the Church of St. Thomas of Villanova in Castel Gandolfo. In: Proceedings of the 4th ISPRS International Workshop 3D-ARCH 2011. ISPRS JOURNAL
OF PHOTOGRAMMETRY AND REMOTE SENSING, vol. Volume XXXVIII-5/W1, Trento.

Carbonara, G., 1985, Restauro dei monumenti, guida agli elaborati grafici, Roma,.

Docci, M., Maestri D., 2009, Manuale

del rilevamento architettonico e urbano, n.e. Laterza Editore, Bari

Enlart C., 1894, Origines françaises de l'architecture gothique en Italie, Thorin et fils, Parigi,

Farina F. and Fornari B., 1978, L'architettura cistercense $e$ l'abbazia di Casamari, Edizioni Casamari, Casamari, $\left(2^{\circ}\right.$ ed. 1981)

Francovich R., Parenti R., (ed.), 1988, Archeologia e restauro dei monumenti, Ciclo di lezioni sulla ricerca applicata all'archeologia, Certosa di Pontignano (Siena), 28 settembre 10 ottobre.

Harris E.C., 1979, Principles of archaeological stratigraphy, London.

Marino, L., 1990, Il rilievo per il restauro: ricognizioni, misurazioni, accertamenti, restituzioni, elaborazioni. - Milano, Hoepli.

Picuti M.R., 2006, Nuove ricerche su Cereatae Marianae (Casamari, Frosinone), in Ghini G., a cura di, In "Lazio e Sabina, 3, Atti del Convegno, Roma, 18-20 novembre 2004", Roma, pp. 297-304.

Picuti M.R., 2008, Museo dell'Abbazia di Casamari. La raccolta archeologica, Edizioni Casamari, Veroli.

Rondinini F., 1707, Monasterii sanctae Mariae et sanctorum Johannis et Pauli de Casaemario brevis historia, Roma.

Scaccia Scarafoni, E., 1962, Il chiostro di Casamari, Istituto Poligrafico dello Stato, Libreria dello Stato Roma, 1962, pubblicato anche in "Palladio", n.XII, pp.11-17. 